\title{
Influence of Source Input on Spatial-temporal Variations of PHC in Jiaozhou Bay
}

\author{
Dongfang Yang ${ }^{1,2,}$, Haixia $\mathrm{Li}^{1}$, Dong Lin ${ }^{1}$, Yuan Zhang ${ }^{1}$, Qi Wang ${ }^{1}$ \\ ${ }^{1}$ Accountancy School, Xijing University, Xian 710123, China \\ ${ }^{2}$ North China Sea Environmental Monitoring Center, SOA, Qingdao 266033, China \\ adfyang_dfyang@126.com
}

Keywords: Petroleum hydrocarbon, Spatial distribution, Pollution, Influence, Source.

\begin{abstract}
This paper analyzed the influence of source input on spatial-temporal variations of Petroleum hydrocarbon (PHC) in Jiaozhou Bay using investigation data on PHC in May and August 1990. Results showed that the contents of PHC in May, and August 1990 in surface waters in Jiaozhou Bay were 0.018-0.270 $\mathrm{mg} \mathrm{L}^{-1}$ and 0.020-0.081 $\mathrm{mg} \mathrm{L}^{-1}$, respectively. In May 1990, PHC contents in estuary of Dagu River were confirm to Class III (moderate polluted), compared to Class I (include II) in other regions (slight polluted). In August 1990, PHC contents in estuary of Haibo River were confirm to Class III (moderate polluted), compared to Class I (include II) in other regions (slight polluted). Dagu River and Haibo River were the major PHC sources in May 1990, while Haibo River was the major PHC source in August 1990. For a same source (i.e., Haibo River), the source strength in May was three-fold to what in August. For a same investigation time (i.e., May), the source strength of PHC in Dagu River was ahead of what in Haibo River. The spatial-temporal variations of the source input from river discharge were influencing the spatial-temporal changes of PHC contents in Jiaozhou Bay.
\end{abstract}

\section{Introduction}

Jiaozhou Bay is a semi-closed bay located in south of Shandong Peninsula, eastern China [1-2]. Along with the rapid development of economic since the Reform and Opening-up, a large amount of PHC containing wastes were generated and discharged to the environment [3-6]. Rivers were playing roles of source input paths of pollutants to marine bays [7-8]. Using investigation data on PHC in May and August 1990, this paper analyzed the influence of river discharge on the distributions of PHC in Jiaozhou Bay. The aim of this paper was to analyze the sources and distributions of PHC in this bay, and to provide scientific basis for pollution control and environment protection [9-11].

\section{Study area and data source}

Jiaozhou Bay $\left(120^{\circ} 04^{\prime}-120^{\circ} 23^{\prime}\right.$ E, $\left.35^{\circ} 55^{\prime}-36^{\circ} 18^{\prime} \mathrm{N}\right)$ is located in the south of Shandong Province, eastern China (Fig. 1). It is a semi-closed bay with the total area, average water depth and bay mouth width of $446 \mathrm{~km}^{2}, 7 \mathrm{~m}$ and $3 \mathrm{~km}$, respectively. There are more than ten inflow rivers such as Haibo Rriver, Licun Rriver, and Loushan Rriver [12-13]. The data was provided by North China Sea Environmental Monitoring Center. The investigations were conducted in May and August 1990, respectively. Surface water samples in 13 sampling sites (i.e., 52, 53, 54, 55, 56, 57, 58, 59, 60, 61, 2104, 2105 and 2106) in May and 11 sampling sites (i.e., 52, 53, 54, 55, 57, 58, 59, 60, 61, 2105 and 2106) in August were collected and measured followed by National Specification for Marine Monitoring (Fig. 1) [14]. 


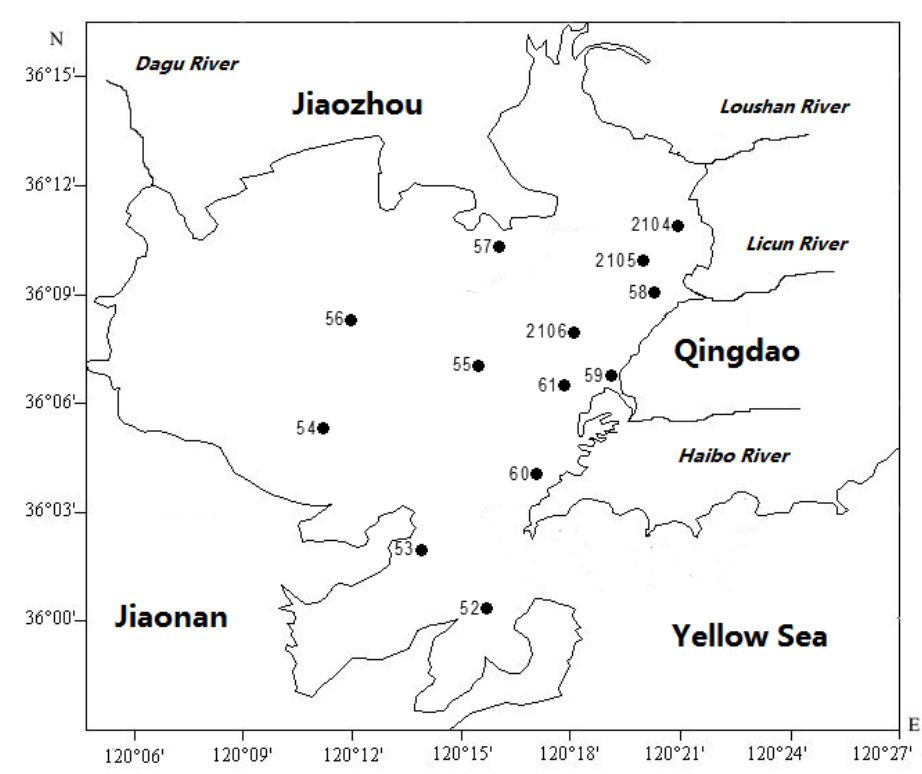

Fig.1 Geographic location and monitoring sites in Jiaozhou Bay

\section{Results and discussion}

\subsection{Horizontal distribution and pollution level of PHC.}

The contents of PHC in May, and August 1990 in surface waters in Jiaozhou Bay were 0.018-0.270 $\mathrm{mg} \mathrm{L}^{-1}$ and 0.020-0.081 $\mathrm{mg} \mathrm{L}^{-1}$, respectively. In May 1990, high value (0.258-0.270 mg $\mathrm{L}^{-1}$ ) of PHC contents was occurring in estuaries of Dagu River and Haibo River, and PHC contents were decreasing from the high value center to along with the flow directions of the rivers (Fig. 2). In August 1990, high value $\left(0.081 \mathrm{mg} \mathrm{L}^{-1}\right)$ of PHC contents was occurring in estuaries of Haibo River, and PHC contents were decreasing from the high value center to along with the flow direction of the river (Fig.3). In Chinese Sea Water Quality Standard (GB 3097-1997), there are 4 classes of water quality for PHC, and the guide lines of Class I (include II), III and IV are $0.05 \mathrm{mg}$ $\mathrm{L}^{-1}, 0.30 \mathrm{mg} \mathrm{L}^{-1}$ and $0.50 \mathrm{mg} \mathrm{L}^{-1}$, respectively. In May 1990, PHC contents in estuary of Dagu River were confirm to Class III (moderate polluted), compared to Class I (include II) in other regions (slight polluted). In August 1990, PHC contents in estuary of Haibo River were confirm to Class III (moderate polluted), compared to Class I (include II) in other regions (slight polluted). In general, the horizontal distributions and pollution levels of PHC in this bay were strongly influenced by river discharge.

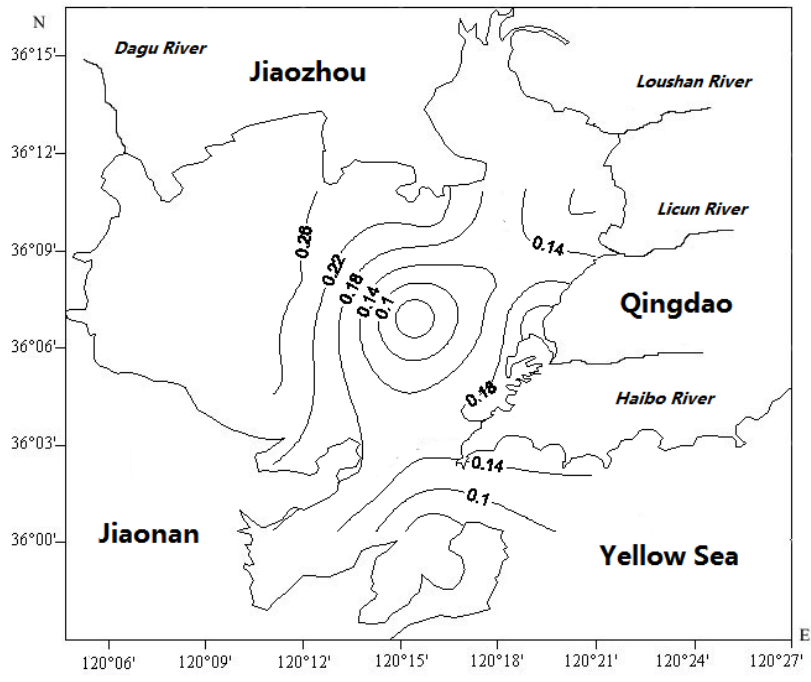

Fig. 2 Horizontal distributions of PHC in Jiaozhou Bay in May 1990/mg L ${ }^{-1}$ 


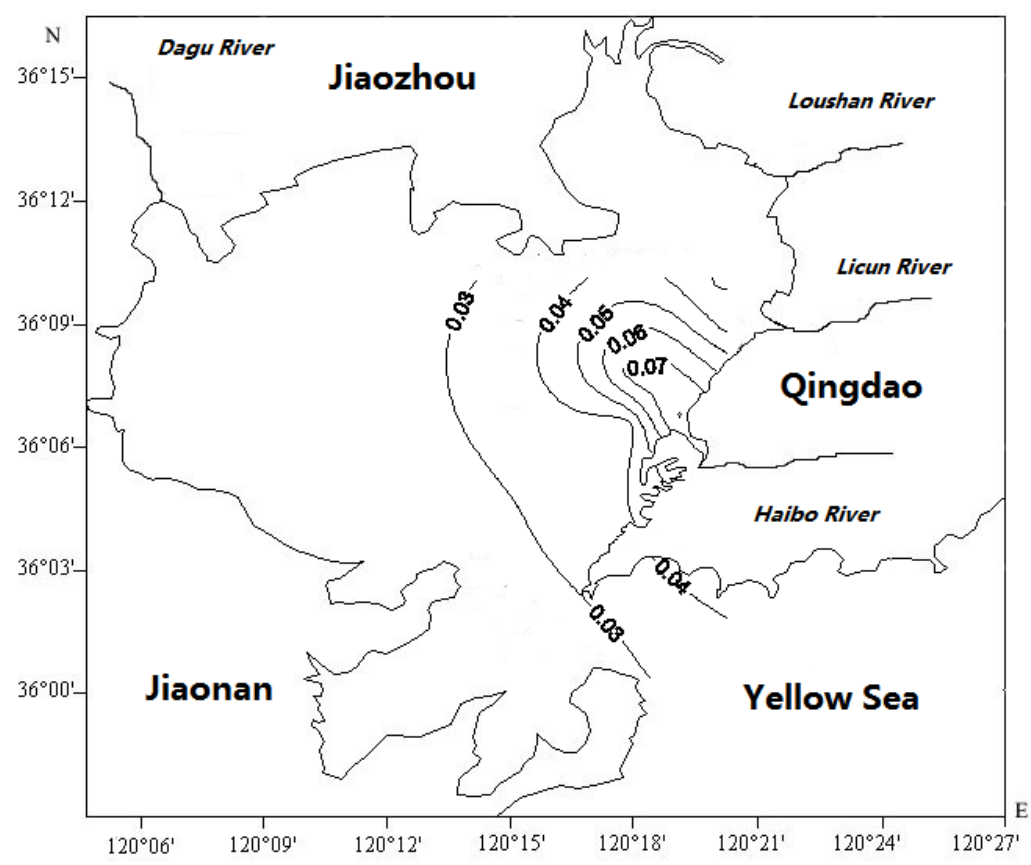

Fig. 3 Horizontal distributions of PHC in Jiaozhou Bay in August 1990/mg L ${ }^{-1}$

\subsection{Source input of PHC.}

The contents of PHC in surface waters were impacted by source input directly, and therefore the source of PHC could be identified by the horizontal of PHC. In May 1990, high value of PHC contents was occurring in estuaries of Dagu River and Haibo River, and PHC contents were decreasing along with the flow directions of Dagu River and Haibo River (Fig. 2). This indicated that Dagu River and Haibo River were the major PHC sources in May 1990. In August 1990, high value $\left(0.081 \mathrm{mg} \mathrm{L}^{-1}\right)$ of PHC contents was occurring in estuaries of Haibo River, and PHC contents were decreasing along with the flow direction of Haibo River (Fig.3). This indicated that Haibo River was the major PHC source in August 1990. In according to Chinese Sea Water Quality Standard (GB 3097-1997), the pollution levels of the major sources were all belong to Class III (Table 1). However, the source strengths were showing spatial and temporal various features. For a same source (i.e., Haibo River), the source strength in May was three-fold to what in August. For a same investigation time (i.e., May), the source strength of PHC in Dagu River was ahead of what in Haibo River. In general, the spatial-temporal variations of the source input from river discharge were influencing the spatial-temporal changes of PHC contents in Jiaozhou Bay.

Table 1 Sources of PHC in Jiaozhou Bay 1990

\begin{tabular}{cccc}
\hline Month & Source & Source strength $/ \mathrm{mg} \mathrm{L}^{-1}$ & Pollution level \\
\hline May & Dagu River & 0.270 & Class III \\
May & Haibo River & 0.258 & Class III \\
August & Haibo River & 0.081 & Class III \\
\hline
\end{tabular}

\section{Conclusion}

The contents of PHC in May, and August 1990 in surface waters in Jiaozhou Bay were 0.018-0.270 $\mathrm{mg} \mathrm{L}^{-1}$ and 0.020-0.081 $\mathrm{mg} \mathrm{L}^{-1}$, respectively. In May 1990, PHC contents in estuary of Dagu River were confirm to Class III (moderate polluted), compared to Class I (include II) in other regions (slight polluted). In August 1990, PHC contents in estuary of Haibo River were confirm to Class III (moderate polluted), compared to Class I (include II) in other regions (slight polluted). Dagu River and Haibo River were the major PHC sources in May 1990, while Haibo River was the major PHC source in August 1990. The spatial-temporal variations of the source input from river 
discharge were influencing the spatial-temporal changes of PHC contents in Jiaozhou Bay.

\section{Acknowledgments}

This research was sponsored by Doctoral Degree Construction Library of Guizhou Nationalities University, the China National Natural Science Foundation (31560107) and Research Projects of Guizhou Nationalities University ([2014]02), Research Projects of Guizhou Province Ministry of Education (KY [2014] 266), Research Projects of Guizhou Province Ministry of Science and Technology (LH [2014] 7376).

\section{References}

[1] Yang DF, Zhang YC, Zou J, et al.: Open Journal of Marine Science, vol. 2 (2011), p. 108-112

[2] Yang DF, Sun PY, Chen C, et al.: Coastal Engineering, Vol. 32 (2013), p. 60- 72. (in Chinese)

[3] Yang DF, Sun PY, Ju L, et al.: Applied Mechanics and Materials, Vol.644-650(2014), p. 5312-5315.

[4] Yang DF, Sun PY, Ju L, et al.: Proceedings of the 2015 international symposium on computers and informatics, vol, (2015), p. 2647-2654.

[5] Yang DF, Wang FY, Zhu SX, et al.: Proceedings of the 2015 international symposium on computers and informatics, Vol. (2015), p. 2661-2666.

[6] Yang DF, Sun PY, Ju L, et al.: Proceedings of the 2015 international symposium on computers and informatics, Vol. (2015), p. 2675-2680.

[7] Yang DF, Zhu SX, Wang FY, et al.: 4th International Conference on Energy and Environmental Protection, Vol. (2015), p. 3784-3788.

[8] Yang DF, Wang FY, Zhu SX, et al.: Advances in Engineering Research, Vol. (2015), p. 431-434.

[9] Yang DF, Wang FY, Zhu SX, et al.: Meterological and Environmental Research, Vol. (2015), p. 31-34.

[10] Yang DF, Zhu SX, Wang FY, et al.: Advances in Engineering Research, Vol. (2016), p. 1351-1355.

[11] Yang DF, Wang FY, Zhu SX, et al.: Meterological and Environmental Research, Vol. (2016), p. 44-47.

[12] Yang DF, Chen Y, Gao ZH, et al.: Chinese Journal of OceanoLogy and LimnoLogy, Vol. 23(2005), p. 72-90.

[13] Yang DF, Wang F, Gao ZH, et al. Marine Science, Vol. 28 (2004), p. 71-74. (in Chinese)

[14] China's State Oceanic Administration: The specification for marine monitoring (Ocean Press, Beijiang 1991), p.1-300. (in Chinese) 